ROBERT J. GORDON

University of Chicago

and the National Bureau of Economic Research

\title{
The Recent Acceleration of Inflation and Its Lessons for the Future
}

The BeST-KNOWN ECONOMIC FACT in the United States, among economists, investment advisers, housewives, and everyone else, is that the rate of inflation has been significantly higher during the past two years than at any time since the Korean war. It has increased despite the best efforts of Washington policy makers to restrain it through, first, the tax surcharge of July 1968; second, a reduction in the growth of the money supply virtually to zero beginning in June 1969; and third, a strenuous effort by the administration to reduce federal expenditures even to the point of the veto of a large education bill. ${ }^{1}$

\section{The Facts}

Although the consumer price index (CPI) monopolizes public attention, economists are concerned with a multitude of price indexes. Between 1966 and 1969, the acceleration of the CPI has been more dramatic than

1. This paper reports an application of a model developed in detail in a paper, "Problems in Predicting the Rate of Inflation," presented to the Econometric Society meetings in New York in December 1969. A revised version of that paper has been submitted for publication, and readers are referred to it for a technical discussion of data and estimation problems. My continuing work in this area is supported by a grant to the National Bureau of Economic Research from the Alfred P. Sloan Foundation. 
the behavior of other indexes. Four-quarter rates of change of the CPI are shown in column 1 of Table 1, and the rates in 1968 and 1969 are clearly the highest for any postwar year since 1951. For the nonfarm private deflator (NPD), which covers the output of the economy other than the government and farm sectors, the 1969 rate of increase is the highest since 1951, but the rate in 1968 was lower than that in 1956 and was only moderately above that for 1966 . The excess of the CPI rate over the NPD rate was unusually high in 1968 and 1969, reflecting the coverage of some items, including home mortgage costs and farm prices (column 3 ), by one series but not the other. Finally, while the rate of increase of these three

\section{Table 1. Annual Rates of Change for Selected Indicators of Prices during Four-Quarter Intervals, 1951-69}

Percentage points

\begin{tabular}{ccccc}
\hline $\begin{array}{c}\text { Year ending } \\
\text { fourth } \\
\text { quarter }\end{array}$ & $\begin{array}{c}\text { Consumer } \\
\text { price } \\
\text { index } \\
(1)\end{array}$ & $\begin{array}{c}\text { Nonfarm } \\
\text { private } \\
\text { deflator } \\
(2)\end{array}$ & $\begin{array}{c}\text { Wholesale } \\
\text { price index } \\
\text { for farm } \\
\text { products } \\
(3)\end{array}$ & $\begin{array}{c}\text { Nonfarm } \\
\text { private } \\
\text { compensation } \\
(4)\end{array}$ \\
\hline 1951 & 6.49 & 5.27 & 6.93 & 7.70 \\
1952 & 1.38 & 2.80 & -8.05 & 5.40 \\
1953 & 0.75 & 2.84 & -7.95 & 4.48 \\
1954 & -0.53 & 2.11 & -2.52 & 2.82 \\
1955 & 0.32 & 1.99 & -8.06 & 3.93 \\
1956 & 2.60 & 3.88 & 4.44 & 6.88 \\
1957 & 3.05 & 2.93 & 4.04 & 4.94 \\
1958 & 1.92 & 1.49 & -0.30 & 3.58 \\
1959 & 1.45 & 1.73 & -6.29 & 4.15 \\
1960 & 1.43 & 1.18 & 3.94 & 3.41 \\
1961 & 0.74 & 0.79 & -2.05 & 4.22 \\
1962 & 1.31 & 0.74 & 3.04 & 3.69 \\
1963 & 1.38 & 1.18 & -3.56 & 3.90 \\
1964 & 1.18 & 1.55 & -1.47 & 4.65 \\
1965 & 1.84 & 0.88 & 7.91 & 3.90 \\
1966 & 3.55 & 3.18 & 1.98 & 6.53 \\
1967 & 2.82 & 3.11 & -5.25 & 5.50 \\
1968 & 4.67 & 3.60 & 5.13 & 8.22 \\
1969 & 5.84 & 4.50 & 7.51 & 6.23 \\
\hline
\end{tabular}

Sources: Consumer price index, U.S. Bureau of Labor Statistics; nonfarm price deflator, computed from U.S. Office of Business Economics, National Income and Product Accounts of the United States, 1929-1965: Statistical Tables, and Survey of Current Business, various issues; farm products, U.S. Office of Business Economics, Business Statistics, 1967, and Survey of Current Business, various issues; nonfarm private compensation, U.S. Bureau of Labor Statistics, "Productivity, Wages, and Prices," various issues. 
price series rose in 1968 and again in 1969, the aggregate hourly wage series (column 4) slowed down substantially in 1969 from its rapid 1968 pace. In fact, the increase in the wage series was smaller in 1969 than in 1956 and 1966.

The acceleration in prices of 1969 was particularly notable against the background of a decelerating growth of real output. Starting with the fourth quarter of 1968, real GNP grew consistently less rapidly than its potential. From the fourth quarter of 1968 to the fourth quarter of 1969 , the advance in real GNP was only $1 \frac{1 / 2}{2}$ percent. The professional forecasts prevailing at the beginning of 1969 generally foresaw this slowdown in the pace of real output, but they predicted an accompanying deceleration in prices that was not realized.

Was there something new and different about the price performance of 1969 ? Or can it be explained on the basis of experience prior to that period? What does it tell about the prospects for combining high employment and price stability in the years ahead? In particular, does the recent experience on prices and unemployment square with the avowed goal of public policy to achieve an unemployment rate of 4 percent, or more precisely 3.8 percent, accompanied by relative price stability? And does it augur well for the policy scenario of the Council of Economic Advisers, in which inflation is reduced to a moderate rate by a small temporary increase in the unemployment rate above 4 percent between early 1970 and mid1971, followed by a return in 1972 to a 3.8 percent unemployment rate? ${ }^{2}$

\section{Explaining the Facts}

The primary aim of this paper is to present answers to these questions, explaining recent price performance and presenting a detailed projection of the quarterly rate of inflation that would accompany the council's projection of the course of output and employment during 1970-75. The paper is thus an application to issues of current interest of my larger effort

2. See the Economic Report of the President together with the Annual Report of the Council of Economic Advisers, February 1970, p. 85, where for 1970 and 1971 the council projects a small gap between actual output and the potential output the economy could produce at a 3.8 percent unemployment rate, and its elimination after mid-1972. According to equation (2) in App. B to this paper, this gap is closely related to the unemployment rate, and so the council's gap diagram can be directly translated into statements about the unemployment rate. 
to develop price forecasting equations by translating into formal econometric terms alternative theories of the determinants of price and wage movements. One major purpose of my research is to test the accelerationist hypothesis, associated in the professional economics literature with the names of Milton Friedman and Edmund Phelps. According to the accelerationist view, the cost of maintaining low unemployment rates-lower than some unspecified "natural" rate-is not a mild and steady rate of price increase, but rather an accelerating and increasingly severe inflation. As Henry Wallich has put it:

There has been a school of thought that has advocated the use of inflation as a means of raising employment. There was a trade-off, so we were told, between inflation and unemployment.... Recent experience has made clear that this is a fallacy. The theory rests on the assumption that inflation does not tend to accelerate. At the very low rates of unemployment that we have been fortunate to have, inflation unfortunately has not remained constant. It has speeded up, because people have observed what went on and protected themselves-by raising wages, interest rates, and prices.... Over a few months, no doubt, the trade-off between inflation and unemployment can always be practiced. In the longer run, it cannot. ${ }^{3}$

A natural conclusion suggested by the accelerationist view (although subscribers to it are usually reluctant to attach specific numbers to their analysis) is that the average unemployment rate of 3.7 percent during 1966-69 was too low and caused an accelerating inflation in the last few years, and that therefore the rate must be significantly raised if an accelerating inflation is to be avoided.

As I have explained in the paper cited above, my equations do not validate the accelerationist hypothesis, although they originate in and follow its framework. Rather, they confirm the Phillips curve argument that a reduction in the unemployment rate can be traded off against a higher but ultimately stable rate of inflation. If high value is placed on a low unemployment rate like the 1966-69 average, the associated inflation will at least be steady rather than accelerating, even though it may be substantial. The equations that refute the accelerationist hypothesis are able accurately to reproduce the quarterly pattern of inflation in the nonfarm private deflator for 1964-69 given information only on unemployment, changes in output, productivity, and social security tax rates, and increases in prices and

3. Henry C. Wallich, "The Uphill Battle Against Inflation," remarks at the Trustees' Dinner, Clarkson College of Technology, Potsdam, N.Y., Jan. 30, 1970. 
wages inherited from 1963. They do not require any direct information on the 1964-69 behavior of wages, prices, or profits.

Since these equations have been reasonably successful in tracking past performance, they can be used to explain the acceleration of prices since 1968 , and also to appraise the likely combinations of rates of inflation and of unemployment in the period 1970-75.

\section{The Explanation of Changes in Prices and Wages}

\section{THE PRICE EQUATION}

Like most research in this area, my econometric efforts divide the analysis of inflation into two parts: the determination of prices given wage costs and the determination of wages given prices. The price equation includes four variables that were found to be highly significant when fitted to quarterly data from 1951 through 1969: standard unit labor costs, actual unit labor costs, the ratio of factory orders to shipments, and an adjusted employment rate.

Standard unit labor cost. The relation of prices to unit labor costs (that is, the wage rate divided by labor productivity) seems roughly consistent with the hypothesis that prices are set to yield a target rate of return at some standard level of capacity utilization, or that they are set to exceed labor cost by some constant markup fraction at that standard utilization level. The role played by the standard utilization level reflects the judgment, supported by numerous studies reporting on interviews with businessmen, that firms will not in general raise prices in response to an increase in labor costs caused by low productivity arising from an economic slowdown, as they would in response to an increase in wage rates at some given level of productivity. Thus in either the target-rate-of-return or markup theory of pricing, the pivotal variable is what I shall call standard unit labor cost, defined as the wage rate $(w)$ divided by an estimate of what productivity would be if the economy were operating continually at full capacity, or standard productivity $\left(q^{\prime}\right)$.

Actual unit labor cost. My estimate of standard productivity simply assumes that it increases at a steady rate between its cyclical peaks, reached in 1947, 1950, 1955, and 1966. During the long interval of slow growth between 1955 and 1966, actual productivity dipped substantially below the standard productivity trend line. Firms may have made the erroneous assumption that long-run productivity growth had slowed down perma- 
nently, and thus they may have estimated standard productivity at a level below $q^{\prime}$. To allow for this possibility, I include actual unit labor cost $(w / q)$ in addition to standard unit labor cost in the price equation and let the data determine the relative weights on each in the pricing process.

Ratio of new orders to shipments. The markup fraction should not be expected to remain constant but instead to depend on excess demand in the market for goods. During rapid expansion in output, with new orders flowing in faster than firms can convert them into shipments, the markup fraction may be raised in the belief that price resistance is weak. When shipments catch up with orders, however, the markup margin may return to its previous level. An excess demand variable is suggested not only in modern markup pricing theories, but also in the more traditional classic theories of perfect competition. There are many possible candidates for an excess demand variable; my choice is the ratio of new orders to shipments $(O / S)$.

The employment rate. In a classical view of the labor market, firms equate the marginal product of labor to the real wage of workers. And the marginal product declines at high rates of employment as more workers are added to a relatively fixed stock of capital. Thus an increase in employment can be achieved only if the real wage is reduced, which, for a given nominal wage rate, requires a price increase. In short, the ratio of prices to wages at standard capacity becomes an increasing function of the employment rate, and the employment rate therefore becomes a variable in the price equation. The adjusted employment rate used in this paper is described below.

Because changes in price, output, or inputs impose substantial transaction costs, a change in a variable determining the price level should not be expected to exert its influence immediately. Thus the current price level may depend not only on the current value of variables like unit labor cost, but also on their past values. After extensive experimentation, I found that the explanatory power of the equation was enhanced significantly by the inclusion of the past values of standard unit labor cost, but that past values of the other variables do not have an important influence on price behavior. The final statistically estimated price equation is:

$$
\begin{aligned}
& \text { (1) } g_{p_{t}}=0.7531 g_{\left(w / q^{\prime}\right)_{L}}+0.1939 g_{(w / q)_{t}}+0.0881 g_{(O / S)_{t}}+0.1518 g_{m_{t}} \\
& \text { (15.062) (5.036) (7.050) } \\
& R^{2}=0.899 \text {, Durbin-Watson }=0.93 \text {, standard error }=0.0053 \text {. }
\end{aligned}
$$

in which 
$g_{p_{t}}=$ the percentage growth rate in the nonfarm private deflator $g_{\left(w / q^{\prime}\right)_{L}}=$ the percentage growth rate in standard unit labor cost, with the $L$ subscript indicating that the coefficient is the sum of a series of distributed lag coefficients (set out in Appendix A)

$g_{(w / q)_{t}}=$ the percentage growth rate in actual unit labor cost

$g_{(O / S)_{t}}=$ the percentage growth rate in the ratio of new orders to shipments

$g_{m_{t}}=$ the percentage growth rate in the total employment rate of manhours in the entire economy.

All variables are expressed as changes over four-quarter intervals. As indicated by the $t$ ratios, shown in parentheses below the estimated coefficients, these four variables are very significant statistically. In addition to these variables, the excise tax rate, farm prices, and the wage-price guideposts (expressed as a dummy variable in the 1962-66 period) were given an opportunity to improve the historical explanation of prices. But they did not play a noticeable role in the price determination process during the 1951-69 period.

The coefficients on standard and actual unit labor cost add up to 0.95 , indicating that a 1 percent increase in the wage rate will ultimately lead to a 0.95 percent increase in the price level. The coefficient on standard unit labor cost, 0.75 , is the sum of a series of coefficients on current and lagged values of $w / q^{\prime}$, and the pattern of coefficients on the lagged values indicates that the adjustment of price to a change in wage rates is virtually complete within nine months. ${ }^{4}$ The coefficient of about 0.2 on actual unit labor cost suggests that when wage rates are constant, a 1 percent decline in the rate of growth of productivity below the standard rate (of about 2.65 percent per annum) increases the price level by about 0.2 percent. The coefficients on the $O / S$ and $m$ variables suggest that in a business expansion, with a rate of increase of 1 percent per annum in both variables, the ratio of price to unit labor cost would rise by about 0.25 percent. Thus excess demand

4. These results do not depend on the statement of variables as four-quarter changes. Other versions of the price equation have been estimated with the variables expressed in level form and as one-quarter changes, and the estimated lag distribution, relative size of coefficients on $w / q^{\prime}$ and $w / q$, and most other aspects of the fourquarter equation are surprisingly stable. The only important difference is that the coefficient on $O / S$ becomes insignificant when the level equation is estimated using a first-order autoregressive transformation. 
in the markets for both goods and labor can initiate inflation even when labor costs are constant.

How well does the price equation explain fluctuations in the rate of inflation in the postwar United States? The equation tracks all major fluctuations in the rate of inflation with reasonable accuracy and estimates quite closely the magnitude of price increases in the three inflationary periods of 1951, 1956-57, and 1966-69. The most noticeable errors are a prediction of a reduction in the rate of inflation in 1957 two quarters too soon, and an overestimate of the inflation rate in late 1968 and early 1969 by about 0.5 percent per annum. The relatively large error in this period is due to the failure of actual prices to respond to the unusual wage increases of 1968 as much as the equation predicts. By the end of 1969 , however, the equation is back on target. In general the errors are very small, and the equation-at least retrospectively-is a good guide for policy, if predictions of wage rates can be provided. I now turn to that task.

\section{THE DETERMINATION OF WAGE RATES}

The wage equation involves four explanatory variables-the adjusted employment rate, the expected rate of change of consumer prices, the rate of change of output, and the rate of change oî the social security tax rate. The dependent variable in the wage equation is the rate of change of the wage rate divided by standard productivity or standard unit labor costs. This formulation reflects the view that the response of workers to a given combination of a wage offer and expected price level will depend on their estimate of a normal real wage. What they consider normal will presumably increase over time as the average productivity of labor increases.

The employment rate. The employment rate is the standard measure of pressure on the labor market. In principle, strength of the labor market is evidenced by any increase in manhours whether in the form of a reduction in unemployment, a movement of individuals into the labor force, or an increase in hours. Hence, the employment rate in this wage equation must take account of all three sources of increases in labor input, and not simply a reduction in unemployment, which is represented in the officially published unemployment rate. For this reason I have constructed a new data series, "the total employment rate of manhours," to be used in these wage and price equations. In postwar recessions the new series fluctuates much 
more than the published rate. More important, in the period 1963-65 the new rate is much higher relative to other years than the published rate, and the new rate declines markedly from 1966 to 1969 in contrast with the steady behavior of the published rate. The use of the new employment rate series helps to explain why wage increases were so low in 1963-65 and so high in 1968-69.

The expected rate of change of the price level. Today's labor force is forward-looking and influenced by the expected level of consumer prices in relation to current nominal wages.

The lack of sample surveys or other consistent sets of evidence about the price level the average worker has expected at various dates presents an extremely difficult problem. Only indirect evidence is available. In my research, as in all previous research on price expectations, changes in the expected price level are assumed to be a function of past price changes. Three different methods of estimating the weights on price changes in various past periods were employed. First, weights are assumed to decline geometrically, with highest weights on the most recent period and regularly descending weights on successive periods in the past. This technique requires numerous tests of the wage equation, each for a different assumed weight for price change in the most recent period. Second, a relatively unrestricted and flexible weighting scheme is estimated by the computer as part of the process of estimating the wage equation. Third, since the level of the interest rate on bonds responds to changes in price expectations, the weights on past prices are estimated in an equation explaining the level of the interest rate on bonds as a function of past price changes.

Surprisingly, very similar results are obtained by the second and third methods. The wage equation in this paper uses the third method, with weights obtained from an interest rate equation described in Appendix B. In this equation about 70 percent of the weight in the formation of price expectations depends on price changes in the most recent year, and about 30 percent on price changes from one to three years ago. In the second method somewhat more weight is given to the most recent year.

The rate of change of ouiput. Unfortunately, the wage index for the nonfarm private economy is not based on wage rates, but on total compensation divided by total manhours. This series tends to be sensitive to the mixture of employment among high-wage and low-wage industries. When an economic expansion begins and employment in the high-paying durable goods industries increases, compensation per manhour will rise even if underlying wage rates are constant. Experimentation suggests that the 
rate of change of output is an excellent proxy for this change in the employment mix, and this variable is thus included in the final wage equation.

The social security tax rate. The employers' share of increases in the social security tax rate is included in compensation per manhour. Therefore the change in the effective social security tax rate has been included in the wage equation.

Guideposts. Just as the 1962-66 guideposts were expected to reduce the response of prices to changes in labor costs, so they were expected to reduce wage demands for a given state of the labor market. Some previous studies have indicated that the guideposts significantly reduced wage increases in the early 1960s; this is not confirmed in my research and so no guidepost dummy has been included in the wage equation.

The final wage equation is then:

$$
\begin{aligned}
g_{\left(w / q^{\prime}\right) t}= & -0.4655+0.5025 m_{t}+0.4531 g_{c^{*} t}+0.1726 g_{Q_{L}} \\
& (-7.477) \quad(7.479) \quad(5.035) \\
+ & 0.4066 g_{T S_{t}} \\
& (1.135) \\
R^{2}= & 0.749, \text { Durbin-Watson }=0.627, \text { standard error }=0.0082 .
\end{aligned}
$$

in which

$$
\begin{aligned}
g_{\left(w / q^{\prime}\right)_{t}=} & \text { the percentage growth rate in standard unit labor cost } \\
m_{t}= & \text { the level of the total employment rate of manhours in the entire } \\
& \text { economy } \\
g_{c^{*}}= & \text { the expected rate of change in the consumer price index (set } \\
& \text { out in Appendix B) } \\
g_{Q_{L}}= & \text { the percentage growth rate in output, with the } L \text { subscript indi- } \\
& \text { cating that the coefficient is the sum of a series of distributed } \\
& \text { lag coefficients (set out in Appendix A) } \\
g_{T S_{t}}= & \text { the percentage growth rate in the social security tax rate. }
\end{aligned}
$$

All variables are expressed as changes over four-quarter intervals. The terms in parentheses below the estimated coefficients are $t$ statistics.

According to this equation, the major determinants of wage changes are the level of the adjusted employment rate, the expected rate of change of consumer prices, and the rate of change of output. Although the change in the social security tax rate is not significant by standard statistical tests, its coefficient is of some importance, and it is retained because it is significant in many other versions of the wage equation that have been estimated.

In testing the accelerationist model, the coefficient of the expected price 
variable is critical. If that coefficient were approximately 1 , the equation would foretell an endless wage-price spiral whenever the employment rate exceeded some critical level. But since it is 0.45 , very substantially less than 1 , each successive round of the wage-price spiral at a given employment rate will be smaller than the last, until both wages and prices stabilize at a steady rate of growth.

The simulation results below compute the long-run steady rates of inflation predicted for different employment rates when the wage-price equations are combined. The positive coefficient on the rate of change of output in the wage equation implies that a slow economic expansion will generate less inflation than a fast one at any given employment rate. A slow advance to an employment rate like 96 percent subsequently held constant will not, however, yield a permanent benefit compared with a faster advance to the same rate. Ultimately the rate of inflation will be the same no matter how a given employment rate is approached.

\section{Price Simulations}

TRACKING INSIDE THE SAMPLE PERIOD

How effectively can the final wage and price equations track the actual course of the price level (nonfarm private deflator) during the inflation of the mid-1960s? In a simulation experiment the history of wages and prices through the end of 1963 is fed into the computer, and then the wage and price equations are set loose to estimate the course of inflation over the sixyear period 1964-69 given actual values of the employment rate, output, the social security tax rate, and productivity in that period. Pending further study of the factors that have caused the consumer price index to rise more rapidly than the nonfarm private deflator since mid-1967, the simulation takes as given the difference between the two price indexes. Thus if the simulation underpredicts the nonfarm private deflator, it will also underpredict the consumer price index that enters (with a lag) into the wage equation.

Why run a simulation for a period that is part of the sample period of the fitted equations? A simulation inside the equations' sample period is a less challenging test than, say, a simulation for 1964-69 using coefficients fitted for a sample period ending in 1963. The 1964-69 period is included 
in the sample because the fitted equations are to be used as forecasting devices and are likely to be more accurate when the latest possible information is included. The simulation experiments are designed to test the tracking ability of the forecasting equations during the few years closest to the period of forecast. Errors in the simulations using these equations may indicate whether some aspects of the forecasts are less reliable than others. ${ }^{5}$

Although it is not illustrated here, a simulation experiment for 1964-69 has been performed with equations identical to equations (1) and (2), but estimated for the 1951-63 period. In this shorter period the coefficient on $m_{t}$ in the wage equation and the sum of the labor cost coefficients in the price equation are higher than those in the equations estimated for the full 1951-69 period. Because of these higher coefficients, the wage-price simulation using the 1951-63 equations overestimates the rate of inflation in 1966- 69 by about 1 percentage point per annum, although the time pattern of the inflation is the same as that in the simulation of the 1951-69 equations discussed below. This result is interesting, since policy makers equipped with the 1951-63 equations and correct forecasts of productivity would have overestimated the inflationary impact of demand expansion, whereas in fact the Council of Economic Advisers tended to underestimate the inflation that would occur at a given unemployment rate.

Figure 1 compares the annual rate of change of the nonfarm private deflator with the results of the simulation using the 1951-69 wage and price equations. The results are shown for two-quarter intervals in this and subsequent figures to smooth out minor fluctuations in both the actual and predicted series, although the calculations for the simulation were made for changes over intervals of one quarter. The mean absolute error of the simulation in predicting the one-quarter change in the nonfarm private deflator is 0.17 of a percentage point. The time path of the 196469 inflation is tracked quite accurately, since the simulation is able to reproduce the 1965 slowdown, the rapid 1966 upsurge, the mild decline of 1967 and early 1968, and the upsurge of late 1968 and 1969. The major errors are that the upsurge of early 1966 is predicted to begin about two

5. Since there is no method of forecasting the ratio of new orders to shipments, and thus $g_{(O / S) t}$ must be constrained to be zero in the forecasts, this variable must be constrained to be zero during the 1964-69 simulations. Since changes in $O / S$ were relatively small during these years, this omission has no appreciable impact on the 1964-69 simulation results, and will not, it is thus hoped, cause important errors in the forecasts. 
Figure 1. Actual and Predicted Change in Nonfarm Private Deflator over Two-quarter Intervals at Annual Rate, 1964-69

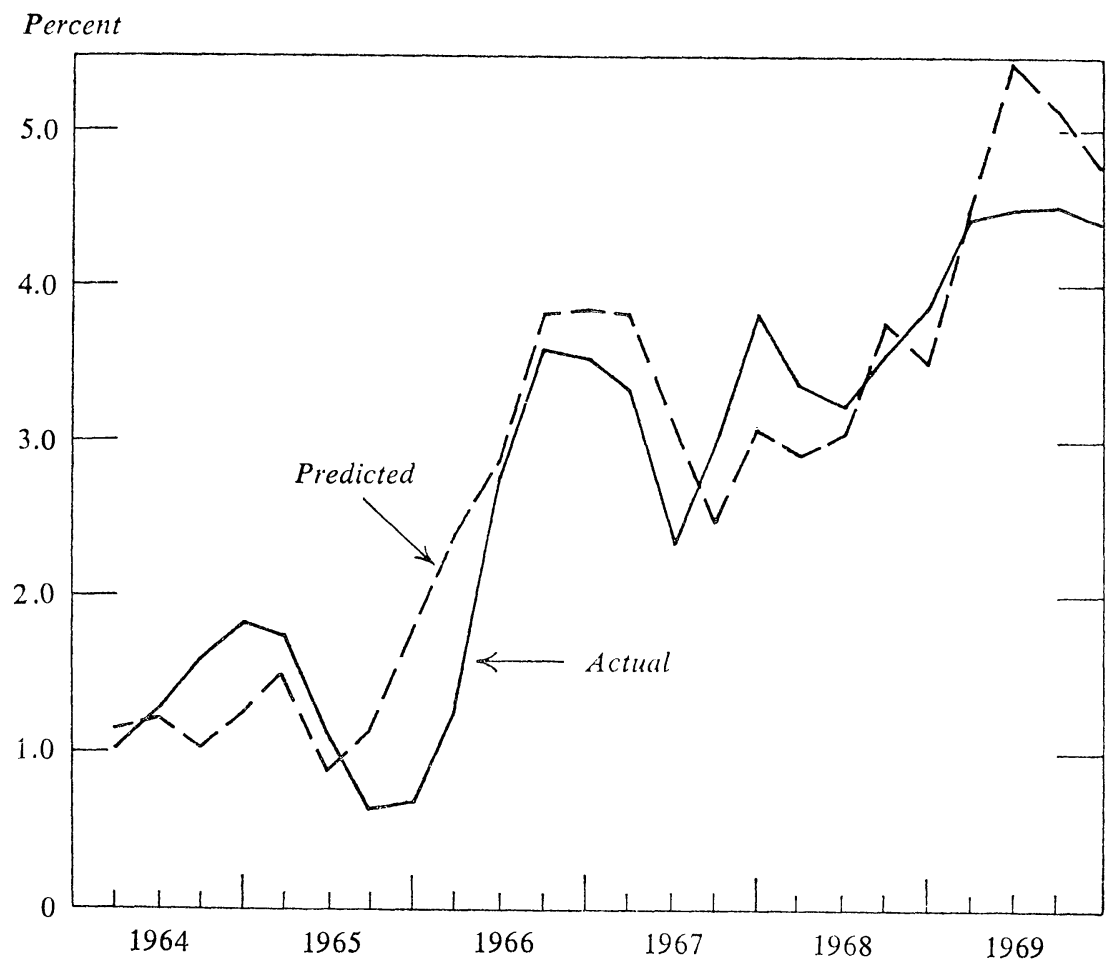

Sources: Survey of Current Business, various issues, and author's estimates.

quarters earlier than it actually did, the inflation rate in late 1967 and early 1968 is underestimated, and the rate in mid-1969 is overestimated. ${ }^{6}$

These errors partially cancel out over the whole period, so that the simulated price level is close to the actual value by the end of 1969 (the values are 1.265 and 1.256 , respectively).

6. In comparing the simulations of these wage and price equations with simulation tests of equations developed by other authors, the reader should note that these simulations are a more challenging test than the forecasting record achieved by a price equation that takes the wage rate as given, but less challenging than simulations performed for large-scale econometric models where variables like the unemployment rate and productivity are explained rather than taken as given, as is the case here. 
CAUSES OF INFLATION, 1964 THROUGH MID-1968

Which explanatory variables are most important in causing the changes of the simulated rate of inflation as illustrated in Figure 1? The most important variable in the model is the total unemployment rate of manhours (described above and shown in column 4 of Table 2), which deter-

Table 2. Determinants of the Rate of Inflation, by Quarter, 1964-69

Percent

\begin{tabular}{|c|c|c|c|c|c|c|}
\hline $\begin{array}{l}\text { Year } \\
\text { and } \\
\text { quarter }\end{array}$ & $\begin{array}{l}\text { Official } \\
\text { unem- } \\
\text { ployment } \\
\text { rate } \\
\text { (1) }\end{array}$ & $\begin{array}{l}\text { Official } \\
\text { unem- } \\
\text { ployment } \\
\text { rate plus } \\
\text { disguised } \\
\text { unem- } \\
\text { ployment } \\
\text { rate } \\
\text { (2) }\end{array}$ & $\begin{array}{l}\text { Unem- } \\
\text { ployment } \\
\text { rate of } \\
\text { average } \\
\text { hours } \\
\text { (3) }\end{array}$ & $\begin{array}{l}\text { Total } \\
\text { unem- } \\
\text { ployment } \\
\text { rate of } \\
\text { manhours } \\
\quad(4)\end{array}$ & $\begin{array}{l}\text { Four- } \\
\text { quarter } \\
\text { rate of } \\
\text { growth of } \\
\text { output } \\
\quad(5)\end{array}$ & $\begin{array}{l}\text { Four- } \\
\text { quarter } \\
\text { rate of } \\
\text { growth of } \\
\text { productivity } \\
\text { (6) }\end{array}$ \\
\hline 19641 & 5.4 & 7.83 & 0.29 & 8.10 & 6.21 & 4.21 \\
\hline 2 & 5.2 & 7.29 & 0.27 & 7.54 & 6.74 & 4.55 \\
\hline 3 & 5.0 & 7.55 & 0.75 & 8.24 & 6.21 & 3.93 \\
\hline 4 & 4.9 & 7.64 & 0.11 & 7.73 & 5.07 & 2.27 \\
\hline 19651 & 4.8 & 7.25 & 0.00 & 7.25 & 5.53 & 2.07 \\
\hline 2 & 4.7 & 7.00 & 0.36 & 7.34 & 5.69 & 2.25 \\
\hline 3 & 4.4 & 6.59 & 0.21 & 6.78 & 6.54 & 2.71 \\
\hline 4 & 4.1 & 6.33 & -0.47 & 5.83 & 8.74 & 4.68 \\
\hline 19661 & 3.8 & 5.71 & 0.01 & 5.72 & 8.46 & 4.65 \\
\hline 2 & 3.8 & 5.69 & 0.27 & 5.95 & 7.97 & 4.20 \\
\hline 3 & 3.8 & 5.15 & 0.12 & 5.26 & 6.43 & 2.65 \\
\hline 4 & 3.7 & 4.58 & 0.21 & 4.78 & 5.00 & 2.54 \\
\hline 19671 & 3.7 & 4.41 & 0.59 & 4.97 & 2.35 & 0.75 \\
\hline 2 & 3.8 & 4.87 & 1.08 & 5.90 & 1.78 & 1.42 \\
\hline 3 & 3.9 & 4.44 & 0.75 & 5.16 & 2.24 & 2.42 \\
\hline 4 & 3.9 & 4.30 & 0.74 & 5.00 & 2.08 & 1.64 \\
\hline 19681 & 3.6 & 3.98 & 0.99 & 4.84 & 4.12 & 3.31 \\
\hline 2 & 3.6 & 3.99 & 0.47 & 4.43 & 5.78 & 3.44 \\
\hline 3 & 3.6 & 4.15 & 0.00 & 4.13 & 5.51 & 2.83 \\
\hline 4 & 3.7 & 4.43 & 0.79 & 5.19 & 5.59 & 3.54 \\
\hline 19691 & 3.3 & 3.07 & 0.51 & 3.56 & 4.67 & 1.87 \\
\hline 2 & 3.5 & 3.58 & 0.00 & 3.57 & 3.05 & 0.46 \\
\hline 3 & 3.6 & 3.30 & -0.44 & 2.75 & 2.58 & -0.04 \\
\hline 4 & 3.6 & 3.20 & 0.01 & 3.21 & 1.74 & -0.53 \\
\hline
\end{tabular}

Sources: U.S. Office of Business Economics, Business Statistics, 1967; Survey of Current Business, various issues; U.S. Bureau of Labor Statistics, "Productivity, Wages, and Prices," various issues; author's estimates. 
mines changes in wage rates and, with a lag, in prices. In early 1964, when the simulation begins, the unemployment rate is 8 percent and there is little inflationary pressure. Although the unemployment rate declines steadily from late 1964 through late 1966, the inflationary impact on the price equation is delayed because of the rapid growth in productivity in late 1965 and early 1966, which reduces actual unit labor cost relative to standard unit labor cost. In 1966 three basic factors contribute to the rapid acceleration of the rate of inflation. First is the cumulative effect of the steady decline in the unemployment rate in 1965 and 1966. Second, the increase in social security taxes in January 1966 gives an immediate boost of 0.41 percent in the wage equation. Finally, the annual rate of growth of productivity slows down from 4.83 percent in the year ending in the first quarter of 1966 to 1.73 percent in the remaining three quarters of that year. This slowdown alone directly causes an increase of 0.6 percent in the ratio of the price level to the average wage rate. A factor moderating the inflation of late 1966 is an easing in the rate of growth of output, a variable that enters the wage equation with a positive coefficient.

In late 1967 and early 1968 the rate of inflation moderates, due to a leveling off in the unemployment rate and a resumption of productivity growth. Furthermore, by 1967 the transitory influence of the early 1966 social security tax increase, which feeds into the price equation with a lag, has worn off. The slackening of the rate of inflation in 1967 and early 1968 , in both the actual and the simulated series, is important evidence against the accelerationist hypothesis, which would have predicted a continual acceleration in the rate of inflation in 1967 and 1968 at the relatively steady 5 percent total unemployment rate of mid-1966 to late 1968 .

\section{THE ACCELERATION OF INFLATION IN 1968-69}

The behavior of the rate of inflation surprised many forecasters in late 1968 and in 1969. As shown in column 5 of Table 2, the rate of change of output slowed from 5.59 percent in the four quarters ending in 1968:4 to 1.74 percent in the following four quarters, yet the slowdown did not lead to a reduction in the rate of inflation, as many experts had expected. The major factors contributing to the recent speedup of inflation can be isolated by an examination of alternative simulations of price behavior beginning in 1968:3, using different values of the explanatory variables. 
Consumer prices. The rate of increase of the consumer price index was considerably higher than that of the nonfarm private deflator in the four quarters ending in 1969:4 (5.84 and 4.50 percent, respectively). Since the past behavior of the consumer price index enters the wage equation, and the control simulation takes as given the difference between the rates of increase of the consumer price index and the nonfarm private deflator, we can ask how much less would the nonfarm private deflator have increased if this difference had been zero instead of the actual amount? The actual difference was used in the control simulation, which is illustrated again as line 1 in Figure 2. The difference was assumed to have

Figure 2. Change in Nonfarm Private Deflator over Two-quarter Intervals at Annual Rate, with Alternative Assumptions about Change in Productivity and Consumer Prices, by Quarter, 1968-69

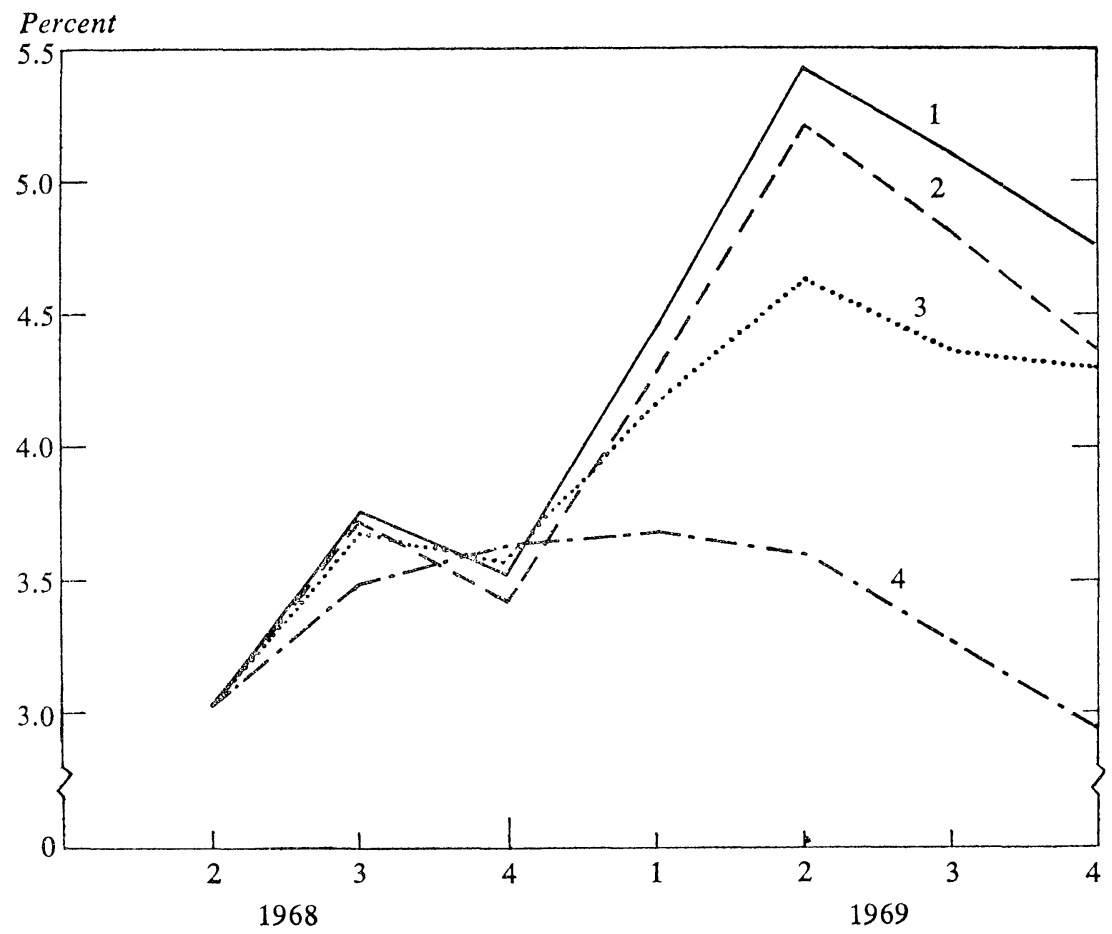

Source: Author's estimates. See text for explanation of the assumptions, keyed to the line numbers. 
been zero in a second simulation, illustrated by line 2 in Figure 2 . The extra inflation contributed by the more rapid growth of the consumer price index is thus represented as the distance between the first and second lines. Although the difference between the consumer and nonfarm private indexes was greatest in the second quarter of 1969, the contribution of this difference, as Figure 2 demonstrates, grows steadily throughout 1969, because in the wage and price equations, changes in consumer prices affect changes in the nonfarm private deflator with a considerable lag. Whether this difference continues to grow in 1970 depends on the behavior of farm prices and the mortgage interest rate, the two biggest components of the consumer price index excluded from the nonfarm private deflator.

Productivity. As shown in the last column of Table 2, productivity not only stopped growing but actually declined in the four quarters ending in 1969:4. This setback was the most important single factor in the 1969 inflation in the control simulation. It prevented the 1969 decline in output growth from moderating the rate of inflation for two reasons. First, it increased the growth of unit labor cost and thus increased the rate of inflation calculated from the price equation for any given rate of growth of wages. Second, the halt in productivity growth prevented the output slowdown from causing an increase in unemployment and induced instead a marked decline in the total unemployment rate of manhours.

If the productivity setback of 1969 surprised economic forecasters and helped to invalidate their inflation forecasts, a calculation of its contribution to inflation requires an assumption of what rate of productivity growth might reasonably have been predicted under the economic conditions of 1969. Equation (3) in Appendix B relates the rate of growth of manhours to the rate of growth of the unemployment rate and a distributed lag of past rates of change of output. Since growth in output affects manhours with a lag, rapid expansion in manhours continues for several quarters after a slowdown in output growth in periods like 1969, and hence improvement in productivity is relatively slight at the beginning of a period of slow output growth. Specifically, equation (3) predicts a reduction in the rate of growth of productivity from 3.30 percent in the four quarters ending in 1968:4 to 1.01 percent in the following four quarters. Instead of falling by 2.29 percentage points as predicted by the equation, however, actual productivity growth between the two periods fell by 4.07 points, from 3.54 to -0.53 percent. It was the excess of the actual drop in productivity growth over a reasonable expectation that surprised forecasters. 
In Figure 2, line 3 illustrates the result of a simulation of price behavior in 1968-69 with the same assumption regarding consumer prices as was made for the second simulation, and in addition with unit labor cost in the price equation calculated on the assumption that productivity grew between 1968:2 and 1969:4 not at its actual rate but rather at the rate predicted by equation ( 3 ). The distance between lines 2 and 3 represents the direct contribution of the unexpected productivity shortfall to inflation through the price equation, given actual wage behavior. The maximum contribution is 0.6 percentage point in 1969:2. The contribution is almost eliminated in 1969:4, because productivity began to grow again in the last quarter of the year, and changes in productivity enter the price equation directly with no lag.

The unemployment rate. A corollary to the surprising decline in productivity in 1969 was the absence of any increase in the official unemployment rate, since high manpower requirements prevented the slowdown in output growth from causing layoffs. Column 1 of Table 2 shows that in the first half of 1969 the official unemployment rate reached the lowest level of the entire 1964-69 period. The official rate, however, underestimates inflationary pressure in the labor market. The high demand for labor resulting from the productivity decline caused an unusual flow of workers into the labor force, which reduced the total of "disguised" unemployed (those who enter the labor force when the chances of obtaining a job improve). The total of the rates of official and disguised unemployment, as shown in column 2 of Table 2, dropped by nearly 1 percentage point between 1968 and 1969, as opposed to a decline of only 0.1 percentage point in the official rate.

The unemployment rate of average hours (column 3) oscillated during 1968 and 1969 but on average was 0.5 point lower in 1969, leading to a drop in the total unemployment rate of manhours between the two years of nearly 1.5 points. If the rate of growth of manhours had followed the path predicted by equation (3) rather than the actual path, the total unemployment rate of manhours would have increased by 0.2 point instead of declining by 1.5 points between 1968 and 1969. In the final simulation, illustrated by line 4 in Figure 2, the assumptions of the third simulation are retained and, in addition, the unemployment rate of manhours is recalculated to follow the path predicted by equation (3). The distance between lines 3 and 4, then, measures the contribution to the 1968-69 inflation of the effect of the unexpected behavior of productivity on the total unem- 
ployment rate and hence on wages, and to a smaller extent, on prices directly through the price equation. If productivity had behaved as predicted by the manhour equation, the total unemployment rate would have been higher, the rate of wage increases would have been lower, and, with a lag, the rate of price inflation would have been lower. The influence of the productivity decline on inflation through the unemployment rate reaches a maximum of 1.3 percentage points in the last quarter of 1969.

The behavior of wages. The simulations calculate a rate of inflation on the basis of coefficients estimated from the entire 1951-69 period and cannot be expected to track actual price experience perfectly in every period. As illustrated in Figure 1, a major error in the control simulation is an overestimate of the rate of inflation during mid-1969. Does this error originate in the wage or price equation? Actual rates of change in wages in 1968 were much higher than predicted, whereas 1969 rates were lower than predicted. Quarter-to-quarter changes in the standard unit labor cost tend to be much more erratic than changes in the nonfarm private deflator, but actual experience deviated further from the values predicted by the wage equation in 1968 than in any other year of the 1951-69 sample period.

The actual rate of advance of the nonfarm private deflator can be compared with two alternative simulations. In the "price-only" simulation, price change is estimated assuming actual rates of wage change. The actual rate of inflation did not respond as much or as rapidly to the 1968 upsurge in wages as predicted by this first simulation, which is based on the price equation estimated for the 1951-69 period. The other simulation is the control solution in which, as before, the behavior of both wages and prices are simulated. Since the wage equation understates wage increases in 1968 and overstates those in 1969, the control simulation predicts slower inflation in 1968 than the price-only simulation, and higher inflation in 1969. Taken together, the two simulations suggest that the control solution was able to track actual inflation in 1968 accurately because of offsetting errors, with an underestimate of wage change canceled out by an overestimate of the response of prices to the predicted values of wage change. In early 1969 the control simulation overstates inflation by a large amount, due to an overestimate of both wage change and the price response. In late 1969 the error is smaller, since the wage overestimate is almost canceled out by an understatement of the price response. 


\section{Forecasts}

THE SHORT-TERM OUTLOOK, 1970-71

Forecasts of price behavior for future periods require forecasts of all of the variables that enter into the price and wage equations. In this paper the aim has been to develop price forecasts without resort to an entire largescale econometric model, and very simple methods have been used to generate forecasts of these explanatory variables. The initial step is the choice of a particular path of real output. Under the assumption of a fixed rate of growth of potential output of 4 percent per year, the gap between actual and potential output can be calculated. The official concept of the unemployment rate is then forecast on the basis of this gap (equation (2), Appendix B). The rate of growth of manhours is then projected as a simple function of the rate of growth of output and of the official unemployment rate, using equation (3). When subtracted from the rate of growth of output, the estimated rate of growth of manhours yields the rate of growth of productivity-equation (4). The difference between the estimated and potential rates of growth of manhours-equation (5) -is the change in the total employment rate in a given quarter. The estimation of the rate of growth of potential manhours raises a difficult issue, discussed in Appendix $\mathrm{B}$. The assumptions made there lead to a relationship between the official and manhour unemployment rates that is roughly similar to that which existed in the first half of the 1960s. In addition, the consumer price index is assumed to rise 10 percent faster than the nonfarm private deflator. Details on all of these relationships among the explanatory variables are outlined in Appendix B.

A critical departure from equation (3) is made in forecasting explanatory variables for the six quarters 1970:1-1971:2. It is assumed that the decline of productivity in 1969 below the levels predicted by the manhour equation was a temporary setback, and that productivity will gradually catch up to predicted levels during 1970-71. A convincing piece of evidence regarding the possibility of a rebound in productivity is the experience of 1956-57. In the four quarters ending in 1956:3, productivity declined by 1.1 percent, an even larger drop than in 1969. During this period actual productivity growth was 1.2 percentage points slower than predicted by the manhour equation, but in the subsequent five quarters a reversal occurred and actual productivity growth was 1.52 percent- 
age points faster than predicted by the equation. Since the situation in $1969-70$ is very similar to that in 1956-57, a period of very slow output growth that followed a year of rapid advance, it may result in a similar catching up in productivity. Thus the basic forecasts in this paper assume an increase in productivity that is 0.25 percent per quarter faster than that predicted by the manhours equation for the period 1970:1-1971:2, for a total rebound of 1.50 percent compared with the 1.68 percent shortfall in productivity growth between 1968:3 and 1969:4.

Given these assumptions regarding explanatory variables, forecasts are

Table 3. Total Unemployment Measures under Alternative Regimes, by Quarter, 1970-75

Percent

\begin{tabular}{|c|c|c|c|c|c|c|c|c|c|}
\hline \multirow{2}{*}{\multicolumn{2}{|c|}{$\begin{array}{c}\text { Year } \\
\text { and } \\
\text { quar- } \\
\text { ter }\end{array}$}} & \multicolumn{2}{|c|}{ Regime $A$} & \multicolumn{2}{|c|}{ Regime $B$} & \multicolumn{2}{|c|}{ Regime $C$} & \multicolumn{2}{|c|}{ Regime $D$} \\
\hline & & $u^{\mathrm{a}}$ & $1-m^{\mathrm{b}}$ & $u$ & $1-m$ & $u$ & $1-m$ & $u$ & $1-m$ \\
\hline \multirow[t]{4}{*}{1970} & & 4.43 & 3.89 & 4.48 & 4.02 & 4.43 & 3.89 & 4.48 & 4.02 \\
\hline & & 4.71 & 4.44 & 5.00 & 4.87 & 4.71 & 4.44 & 5.00 & 4.87 \\
\hline & & 4.83 & 4.91 & 5.43 & 5.68 & 4.83 & 4.91 & 5.43 & 5.68 \\
\hline & & 4.81 & 5.30 & 5.63 & 6.27 & 4.81 & 5.30 & 5.63 & 6.27 \\
\hline \multirow[t]{4}{*}{1971} & & 4.79 & 5.64 & 5.66 & 6.71 & 4.79 & 5.64 & 5.69 & 6.77 \\
\hline & 2 & 4.78 & 5.98 & 5.63 & 7.07 & 4.78 & 5.98 & 5.75 & 7.22 \\
\hline & 3 & 4.70 & 5.89 & 5.62 & 7.18 & 4.78 & 6.08 & 5.83 & 7.43 \\
\hline & & 4.45 & 5.70 & 5.61 & 7.28 & 4.78 & 6.19 & 5.92 & 7.64 \\
\hline \multirow[t]{4}{*}{1972} & & 4.18 & 5.46 & 5.52 & 7.21 & 4.78 & 6.29 & 5.97 & 7.79 \\
\hline & 2 & 3.94 & 5.20 & 5.27 & 7.04 & 4.78 & 6.39 & 5.97 & 7.91 \\
\hline & 3 & 3.76 & 5.15 & 5.01 & 6.84 & 4.78 & 6.49 & 5.96 & 8.02 \\
\hline & t & 3.77 & 5.19 & 4.77 & 6.62 & 4.78 & 6.60 & 5.96 & 8.12 \\
\hline \multirow[t]{4}{*}{1973} & & 3.79 & 5.28 & 4.54 & 6.41 & 4.78 & 6.70 & 5.96 & 8.22 \\
\hline & 2 & 3.80 & 5.28 & 4.33 & 6.11 & 4.78 & 6.70 & 5.96 & 8.22 \\
\hline & 3 & 3.80 & 5.29 & 4.12 & 5.81 & 4.78 & 6.71 & 5.96 & 8.23 \\
\hline & + & 3.80 & 5.29 & 3.92 & 5.50 & 4.78 & 6.71 & 5.96 & 8.23 \\
\hline \multirow[t]{4}{*}{1974} & & 3.80 & 5.29 & 3.77 & 5.37 & 4.78 & 6.71 & 5.96 & 8.23 \\
\hline & 2 & 3.80 & 5.29 & 3.77 & 5.32 & 4.78 & 6.71 & 5.96 & 8.23 \\
\hline & 3 & 3.80 & 5.30 & 3.79 & 5.31 & 4.78 & 6.72 & 5.96 & 8.24 \\
\hline & 4 & 3.80 & 5.30 & 3.80 & 5.31 & 4.78 & 6.72 & 5.96 & 8.24 \\
\hline \multirow[t]{4}{*}{1975} & & 3.80 & 5.30 & 3.80 & 5.32 & 4.78 & 6.72 & 5.96 & 8.24 \\
\hline & 2 & 3.80 & 5.30 & 3.80 & 5.32 & 4.78 & 6.72 & 5.96 & 8.24 \\
\hline & 3 & 3.80 & 5.30 & 3.80 & 5.32 & 4.78 & 6.72 & 5.96 & 8.24 \\
\hline & 4 & 3.80 & 5.30 & 3.80 & 5.32 & 4.78 & 6.72 & 5.96 & 8.24 \\
\hline
\end{tabular}

Source: Author's estimates. See text for explanation.

a. The symbol $u$ is the official unemployment rate.

b. The symbol $m$ is the total employment rate of manhours in the entire economy. 
calculated for four alternative paths, or "regimes," of real output, with implications for the official and total unemployment rates that are set out in Table 3. Regime $\mathrm{A}$ is the path of real output predicted by the Council of Economic Advisers in their Annual Report of February 1970, and assumes a GNP gap that is zero in mid-1969, grows to about 3 percent in mid-1970, stays at this level until mid-1971, and then shrinks back to zero by mid$1972 .^{7}$ This gap implies growth in the official unemployment rate to a maximum of 4.83 percent in the third quarter of 1970 , stability at that level until mid-1971, and then a gradual return to a permanent level of 3.8 percent, the unemployment rate at which actual output is assumed to equal potential.

The consequences of regime A for the rate of inflation through 1971:3 are shown in Figure 3. The control simulation, illustrated by line 1, is based on the forecasts of explanatory variables outlined above, including the assumption of a productivity rebound. The rate of inflation declines rapidly from 4.8 percent in late 1969 to 3.0 percent in mid-1971. Alternative forecasts for regime A are shown by the other lines, which illustrate simulations in which the forecasts of explanatory variables are altered. In the second simulation the ratio of the rate of increase in the consumer price index to that in the nonfarm private deflator is assumed to remain at 1.24, instead of declining to 1.10 , as assumed in the control simulation. This raises the forecast of the rate of inflation in early 1971 by about 0.1 percentage point.

Next, the assumption of a productivity rebound is dropped. The third simulation retains the pessimistic assumption of the second regarding consumer price behavior and in addition calculates unit labor cost on the assumption that productivity grows strictly at the rate computed from the manhours equation with no rebound. The direct contribution of slower productivity growth in the price equation, measured by the difference between lines 2 and 3 in Figure 3, amounts to about 0.25 percent in early 1971 and prevents the rate of inflation from falling below 3.4 percent.

The forecast is changed radically in the fourth simulation, where the absence of a productivity rebound is allowed to affect the unemployment rate. With a productivity level that by $1971: 2$ is 1.5 percent below the control solution, the unemployment rate of manhours is 4.48 percent in that

7. These assumptions are shown explicitly in a diagram in the Annual Report of the Council of Economic Advisers, February 1970, p. 85. 
Figure 3. Change in Nonfarm Private Deflator over Two-quarter Intervals at Annual Rate under Unemployment Measures for Regime A, with Alternative Assumptions on Change in Productivity and Consumer Prices, by Quarter, 1969-71

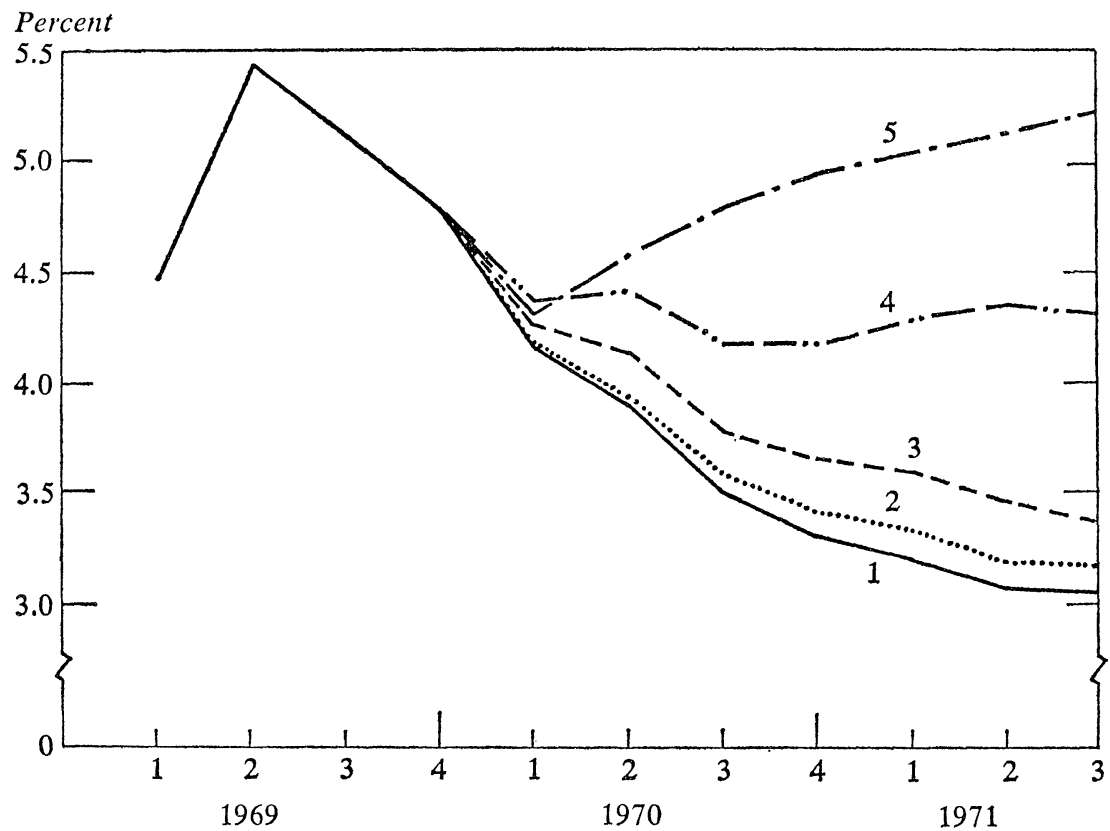

Source: Author's estimates. See text for explanation of the assumptions, keyed to the line numbers, and Table 3 for unemployment measures for regime A.

period instead of 5.98, and by 1971:3 the rate of inflation is almost 1 percent higher than it is in the third simulation and almost as rapid as the actual rate in late 1969. Therefore the assumption of a productivity rebound is essential to the prediction of a reduction in the rate of inflation in 1970-71 under regime A, just as the productivity setback of 1969 is the critical ingredient in explaining the acceleration of inflation last year.

The final simulation in Figure 3, labeled line 5, retains the productivity and consumer price assumptions of the fourth simulation, but assumes a steady rate of growth of output at a 4 percent annual rate beginning in 1970:1. The difference between lines 4 and 5 shows the reduction in inflation, about 0.7 percent, contributed by the 1970 slowdown in output growth under regime $\mathrm{A}$. 
THE OUTLOOK FOR 1970-75 UNDER

\section{ALTERNATIVE REGIMES}

Figure 4 illustrates inflation forecasts under regime $\mathrm{A}$ and several alternative regimes. In each case the behavior of consumer prices and productivity is governed by the same rules as those that govern the control solution for regime A (line 1 in Figure 3 ), that is, by the equations of Appendix B adjusted for the six-quarter productivity rebound between 1970:1 and 1971:2. After the temporary 1970-71 drop in the rate of inflation under regime A, the elimination of the output gap in 1971-72 causes an increase in the rate of inflation to a peak of 4.2 percent in late 1972 , followed by a decline to a steady rate of about 3.7 percent in 197375 . This steady rate is considerably lower than the actual rate of inflation in 1969.

The council's policy of deliberately engineering a temporary output gap can therefore be labeled an exercise in futility if its aim is to reduce inflation to the rates of less than 2 percent characteristic of the early 1960s. A short interlude of 4.8 percent unemployment yields a temporary reduction in the rate of inflation, but by 1972 the elimination of the output gap brings a return of inflation at rates almost as high as the 1969 experience. The steady rate of inflation at a zero output gap, as illustrated in Figure 4, is of course only approximate, and the rate would be higher if productivity were to rebound less than assumed here or if the rate of increase in consumer prices were more than 10 percent higher than that for the nonfarm private deflator. More optimistic assumptions than those underlying the control solution would yield correspondingly slower rates of inflation.

The assumed output path and predicted price level developed here for regime A can be used to calculate the value of GNP in current dollars for the fourth quarter of 1970 on the assumption that the GNP deflator grows at the same rate as the nonfarm private deflator in 1970. A real output level of $\$ 748$ billion combined with a price index of 1.353 means a nominal GNP projection of $\$ 1,012$ billion, considerably higher than that in many current economic forecasts. To evaluate the implications of a lower nominal GNP forecast, an inflation path can be calculated for regime B, which assumes a real output level no higher in the last quarter of 1970 than in the last quarter of 1969 . Under regime B real output resumes growth in 1971:1 at a 4 percent annual rate, and in 1972:1 begins an 
Figure 4. Change in Nonfarm Private Deflator over Two-quarter Intervals at Annual Rate, with Actual Values of Explanatory Variables for 1968-69 and Alternative Values of Explanatory Variables under Unemployment Measures for Alternative Regimes, 1970-75

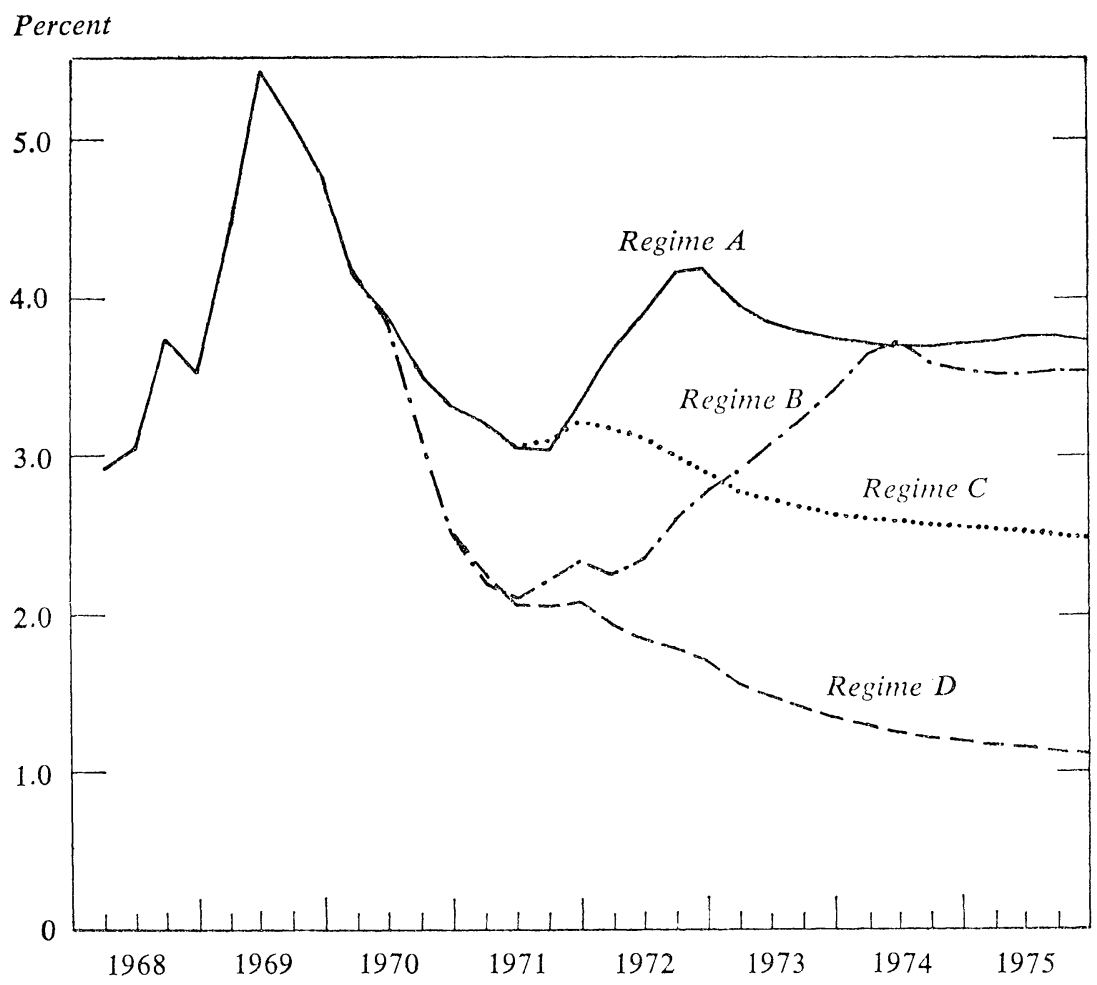

Source: Author's estimates. See text for explanations, and Table 3 for the unemployment measures for the regimes.

eight-quarter return to potential output. The official unemployment rate reaches a maximum of 5.66 percent in $1971: 1$ and by early 1974 returns to the full employment rate of 3.8 percent.

Figure 4 shows the projected inflation rate under regime B dipping to a minimum of 2.1 percent in early 1971 and thereafter returning steadily to roughly the regime A rate. A rebound in the rate of inflation occurs during 1971, despite a constant official unemployment rate and a growing total unemployment rate, because the transient influence of the negative rate of 
growth of output and unemployment variables in the wage and price equations that is partially the cause of the early 1971 trough no longer operates when the economy settles down. Similarly, in both regimes A and B the rate of inflation overshoots its equilibrium values at the end of the period of rapid output growth in late 1972 for regime A and early 1974 for regime B.

Under regime B nominal GNP is $\$ 982$ billion in the fourth quarter of 1970. For readers who predict a value of nominal GNP between $\$ 982$ billion and $\$ 1,012$ billion for 1970:4, the inflation forecast would be between the lines shown for regimes A and B. Given the productivity assumptions made here, an official unemployment rate much below 5 percent in late 1970 appears unlikely even under regime A, but if the productivity rebound is delayed, the increase in the unemployment rate may be slower than shown for either regime A or B.

Regimes C and D assume that the output gap created during 1970 is retained rather than eliminated. If policy makers decide that the resumption of inflation predicted for 1973-75 under regimes A and B is unacceptable, they may reluctantly conclude that a higher unemployment rate must be maintained in order to lower the long-term steady rate of inflation. Under regime $\mathrm{C}$ the official unemployment rate is maintained at about 4.8 percent, a level similar to that of early 1965 . The result is a steady inflation rate of slightly less than 2.5 percent. If such a rate is viewed as excessive, regime $\mathrm{D}$ might be chosen. Under this final alternative the longterm unemployment rate is 6 percent and the steady rate of inflation levels off at about 1.1 percent. This is roughly similar to the rate of price increase in 1963, when the official unemployment rate was close to 6 percent. The combinations of inflation forecasts and official unemployment rates in the forecasts can be plotted in the form of a Phillips curve. The result is a straight line predicting a zero rate of inflation at an official unemployment rate of 6.8 percent, slightly less than the peak of unemployment rates of the 1958 and 1961 recessions.

\section{Conclusion}

This paper has presented simulations and forecasts of the rate of inflation based on price and wage equations estimated for the 1951-69 period. They are based on only one of many possible sets of wage and price equations estimated for only one of many alternative sample periods and by 
only one of many different and equally acceptable statistical techniques. The reader is warned that the exact magnitude of the permanent rates of inflation at alternative steady rates of unemployment is sensitive to minor changes in the estimated equations and in the methods used to forecast explanatory variables. But changes in econometric details do not alter the following principal conclusions:

- At a steady rate of unemployment, the rate of inflation will be stable after a transition period and will not tend to accelerate or decelerate.

- The model presented in this paper is capable of explaining with reasonable accuracy the path of inflation in 1964-69 without recourse to the accelerationist hypothesis.

- The "stop-go" policy of the Council of Economic Advisers, aimed at reducing or eliminating inflation by creating a temporary real output gap followed by rapid output growth to close the gap, will yield a temporary reduction in the rate of inflation as long as the gap is maintained, but the rate of inflation will rise again when the output gap is eliminated.

APPENDIX A

\section{Details on the Estimation of the Price and Wage Equations}

The SAMPle PeRIOD IS 1951:1 to 1969:4. Since data begin in 1947, and thus four-quarter change data begin in 1948, the twelve-quarter distributed lag makes 1951 the earliest year that can be included in the sample period.

The symbol $g$ stands for the percentage growth rate of a variable over a four-quarter interval. Since the observations included in the regressions are quarterly, two successive observations contain as common elements the change over a three-quarter interval. This tends to make the residuals autocorrelated and reduces the Durbin-Watson statistic. Extensive experimentation has revealed that the conclusions are insensitive to changes in the form of variables to two-quarter or one-quarter changes. The price equa- 
tions have also been estimated in levels. The only effect of these changes in estimation technique is small changes in the size (but not in the significance) of various coefficients. Thus they do alter the numerical value of the permanent rate of inflation implied at any given unemployment rate by the wage and price equations interacting together; but none of the substantive conclusions of the paper regarding the causes of inflation is affected.

Four-quarter changes in the variables for the social security tax rate are calculated for the form suggested by the tax-shifting literature: $1 /(1-T S)$.

The subscript $L$ on the standard unit labor cost variable in the price equation and on the output variable in the wage equation indicates that the coefficient is the sum of the coefficients on the current and past values of four-quarter changes in the respective variables. These coefficients were estimated by the Almon polynomial method using a fourth-degree polynomial extending over twelve quarters, which is restricted to force the distant coefficient to equal zero and to force the lag distribution to approach zero smoothly. The individual coefficients on lagged values are as follows:

$\begin{array}{lcc}\text { Period } & \begin{array}{c}g_{\left(w / q^{\prime}\right)_{L}} \\ \text { coefficients }\end{array} & \begin{array}{c}g_{Q_{L}} \\ \text { coefficients }\end{array} \\ t & 0.3541 & 0.1023 \\ t-1 & 0.2541 & 0.0471 \\ t-2 & 0.1435 & 0.0210 \\ t-3 & 0.0531 & 0.0104 \\ t-4 & -0.0065 & 0.0066 \\ t-5 & -0.0335 & 0.0044 \\ t-6 & -0.0340 & 0.0016 \\ t-7 & -0.0182 & -0.0019 \\ t-8 & 0.0018 & -0.0050 \\ t-9 & 0.0155 & -0.0064 \\ t-10 & 0.0171 & -0.0053 \\ t-11 & 0.0079 & -0.0021\end{array}$




\section{Procedures Used To Generate Explanatory Variables}

\section{Expectations Variable}

As described in the text, three alternative methods were employed in the formal tests to generate the variable representing the change in the expected level of the consumer price index. The method chosen for the simulations and forecasts in this paper starts with the hypothesis that changes in the expected rate of inflation are an important determinant of the long-term interest rate. A regression of the interest rate on past price changes can then provide evidence on the relative weights given to various periods in the past in the formation of price expectations. Preliminary tests were made with past price changes as the only variable determining the level of the interest rate, an approach used by W. P. Yohe and D. S. Karnosky. ${ }^{1}$ It was soon evident that the Yohe and Karnosky technique was seriously deficient, explained only a small portion of the variance of the interest rate, and had virtually no explanatory power in the 1950s. Therefore an alternative approach was taken. We postulated, unlike Yohe and Karnosky, that price expectations are not the only variable influencing the interest rate, but that in addition monetary authorities can change the interest rate, at least temporarily, by altering the ratio of money to income. Thus we introduce velocity (nominal GNP divided by currency plus demand deposits) as a variable in our interest rate equation. The $R^{2}$ leaps from 0.50 to 0.94 , and the equation is equally able to explain interest rate behavior in the 1950s and 1960s. Most of the effect on the interest rate of a change in the money-income ratio by the monetary authorities is transi-

1. William P. Yohe and Denis S. Karnosky, "Interest Rates and Price Level Changes, 1952-69," Review-Federal Reserve Bank of St. Louis, Vol. 51 (December 1969), pp. 18-38. 
tory. The following equation ${ }^{2}$ suggests that after five quarters most of the initial effect fades out:

$$
\begin{gathered}
r_{t}=\underset{(-3.987)}{-0.796}+\underset{(5.543)}{19.34 g_{c_{L}}+\underset{(20.05)}{1.219} V_{L}} \\
R^{2}=0.940, \text { Durbin-Watson }=0.62 \text {, standard error }=0.234
\end{gathered}
$$

The change data are one-quarter rates. The sample period is 1952:11969:4. Almon lag details are described on page 35. The following are the Almon lag coefficients and $t$ statistics:

$\begin{array}{lcccc}\text { Period } & \begin{array}{c}g_{c} \\ \text { coefficient }\end{array} & \begin{array}{c}t \\ \text { statistic }\end{array} & \begin{array}{c}V \\ \text { coefficient }\end{array} & \begin{array}{c}t \\ \text { statistic }\end{array} \\ t & - & - & 1.688 & 3.008 \\ t-1 & 3.371 & 3.043 & 0.258 & 1.213 \\ t-2 & 4.199 & 3.662 & -0.424 & -1.500 \\ t-3 & 3.553 & 4.755 & -0.612 & -2.564 \\ t-4 & 2.281 & 3.738 & -0.512 & -2.622 \\ t-5 & 1.016 & 1.194 & -0.287 & -1.361 \\ t-6 & 0.175 & 0.189 & -0.053 & -0.255 \\ t-7 & -0.044 & -0.060 & 0.119 & 0.655 \\ t-8 & 0.340 & 0.579 & 0.205 & 0.914 \\ t-9 & 1.091 & 1.259 & 0.223 & 0.796 \\ t-10 & 1.757 & 1.702 & 0.242 & 1.101 \\ t-11 & 1.666 & 2.310 & 0.371 & 0.749\end{array}$

In the wage equations for this paper the expected price change variable is a weighted average of past price changes, with the weights adding to unity and distributed over past periods as indicated by the coefficients on $g_{c}$ listed above.

\section{Generation of Explanatory Variables}

\section{THE CONSUMER PRICE INDEX}

In period $t$ we generate the nonfarm private deflator, and this must somehow be translated into the consumer price index in period $t$, which is needed to form the expected price variable $g_{c^{*} t_{t+1}}$. Exploratory regressions

2. The definitions for symbols in this and the equations that follow are given in App. C. 
revealed that the rate of change of the consumer price index is determined partly by the nonfarm private deflator (as is to be expected since the two indexes share many common elements-although one is a Paasche and one a Laspeyres index), partly by the rate of change of farm prices, and marginally by the rate of change of the mortgage interest rate. Excluding the latter determinant, which has a very small effect on the results, the best regression explaining the consumer price index is of the form

$$
g_{c_{t}}=0.0001+0.78 g_{p_{t}}+0.32 g_{f_{t}},
$$

with the coefficients estimated in one-quarter rates of change. The puzzling aspect of this regression is the high weight on farm prices, a result caused presumably by a positive correlation between changes in farm prices and changes in excluded variables during the sample period. Since we have no method of forecasting farm prices, we assume that on average the rates of change of $g_{f_{t}}$ and $g_{p_{t}}$ will be identical, so that in our forecasts we generate one-quarter changes in consumer prices by the formula

$$
g_{c_{t}}=0.0001+1.10 g_{p_{t}}
$$

\section{THE OFFICIAL UNEMPLOYMENT RATE}

The rate of change of output in the private economy $\left(g_{Q_{t}}\right)$ is taken as the single exogenous variable in the forecasts, the level of output is calculated, and on the assumptions that aggregate GNP grows as fast as private nonfarm GNP and that potential aggregate GNP grows at an assumed 4 percent per annum, the gap $\left(H_{t}\right)$ between potential and predicted actual output can be obtained. Then the official concept of the unemployment rate is explained by the following nonlinear version of Okun's law, which was estimated for 1951-69 and fits very well during the sample period:

$$
u_{t}=\underset{(48.39)}{0.0366}+\underset{(2.776)}{0.1450} g_{Q_{t}}+\underset{(1.951)}{0.6845} H_{t}^{2}+\underset{(11.520)}{0.2898} H_{L}
$$

$R^{2}=0.931$, Durbin-Watson $=0.63$, standard error $=0.0033$.

The data are in one-quarter rates of change. Almon lag details are as described on page 35. The following are the Almon lag coefficients and $t$ statistics: 


$\begin{array}{lcr}\text { Period } & \text { H coefficient } & t \text { statistic } \\ t & 0.2135 & 5.583 \\ t-1 & 0.0867 & 8.538 \\ t-2 & 0.0172 & 0.928 \\ t-3 & -0.0120 & -0.815 \\ t-4 & -0.0156 & -2.185\end{array}$

\section{PRODUCTIVITY CHANGE}

The exogenous rate of growth of output and of the official unemployment rate are sufficient to generate a prediction of changes in manhours $(M)$ in the private nonfarm economy.

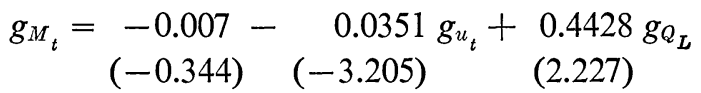

$$
\begin{aligned}
& R^{2}=0.671 \text {, Durbin-Watson }=1.87 \text {, standard error }=0.0056 \text {. }
\end{aligned}
$$

The data are in one-quarter rates of change. Almon lag details are described on page 35. The following are the Almon lag coefficients and $t$ statistics:

$\begin{array}{ccc}\text { Period } & g_{Q} \text { coefficient } & t \text { statistic } \\ t & 0.2623 & 3.676 \\ t-1 & 0.1375 & 3.795 \\ t-2 & 0.0601 & 2.216 \\ t-3 & 0.0175 & 0.815\end{array}$

The rate of growth of productivity is therefore

$$
g_{q_{t}}=g_{Q_{t}}-g_{M_{t}} .
$$

THE TOTAL EMPLOYMENT RATE

According to the manhours equation (3), a rate of growth of potential output of 4 percent is consistent with a rate of growth of potential manhours of 1.64 percent per year, or 0.41 percent per quarter. Starting from the actual value of the total employment rate in the fourth quarter of 1969, subsequent values are calculated by the formula:

$$
m_{t}-m_{t-1}=\left(g_{M_{t}}-0.0041\right) m_{t-1} .
$$

An exception to this procedure is made during part of the 1970-72 period. Compared with the long-term trend of hours, hours per man were 
unusually low during 1967-69, and pending further discussion on the sources of this development, part of it is assumed to be temporary. Hours per man in 1969 were about 0.5 hour below the long-term trend, and 0.37 hour of this shortfall (or 1.0 percent of actual hours) is assumed to be eliminated between 1970:3 and 1972:4. During these quarters, therefore, the rate of growth of potential manhours is assumed to be 0.51 percent per quarter instead of 0.41. If the long-term trend is not resumed, the rates of inflation associated with each of the regimes will be higher than shown in Figure 3.

APPENDIX C

\section{Symbols and Sources of Data Used in Regressions}

\begin{tabular}{|c|c|c|}
\hline Symbol & Name of variable & Source \\
\hline$c$ & Consumer price index, $1958=1.00$ & $\mathrm{BS} / \mathrm{SCB}$ \\
\hline$c^{*}$ & Expected consumer price index, $1958=1.00$ & Appendix B \\
\hline$f$ & Wholesale price index for farm products & $\mathrm{BS} / \mathrm{SCB}$ \\
\hline$g_{x}$ & $\begin{array}{l}\text { Four-quarter percentage growth rate in } x \text {, un- } \\
\text { less specified otherwise (regressions in Ap- } \\
\text { pendix B use one-quarter data and forecasts } \\
\text { are calculated for one-quarter changes) }\end{array}$ & \\
\hline$H$ & Potential output minus actual output & App \\
\hline$L$ & $\begin{array}{l}\text { Subscript indicating coefficient is the sum of a } \\
\text { series of lag coefficients }\end{array}$ & \\
\hline$M$ & Manhours in the nonfarm private sector & BLS \\
\hline$m$ & $\begin{array}{l}\text { Total employment rate of manhours in the en- } \\
\text { tire economy }\end{array}$ & RJG \\
\hline$O / S$ & $\begin{array}{l}\text { Ratio of new orders to shipments in the manu- } \\
\text { facturing sector }\end{array}$ & $\mathrm{BS} / \mathrm{SCB}$ \\
\hline p & Nonfarm private deflator, $1958=1.00$ & SCB \\
\hline
\end{tabular}


$Q \quad$ Nonfarm private output in 1958 prices

$\mathrm{SCB}$

$q \quad$ Output per manhour in the nonfarm private sector

BLS

$q^{\prime} \quad$ Output per manhour at full capacity

RJG

$r \quad$ Interest rate on long-term government bonds (percent)

$\mathrm{BCD}$

$t \quad$ Time period in quarters

TS Social security tax receipts divided by personal income

SCB

$u \quad$ Published unemployment rate

$\mathrm{BS} / \mathrm{SCB}$

$V \quad$ Current-dollar GNP divided by the stock of currency plus demand deposits

$w \quad$ Compensation per manhour in the private nonfarm economy; in price equation adjusted for changes in industry mix (see RJG)

BS/SCB, FRSL

\section{BLS}

Key to sources

$\mathrm{BCD}$

Business Conditions Digest, various issues

BLS Mimeographed releases of the Bureau of Labor Statistics

$\mathrm{BS} / \mathrm{SCB}$ U.S. Office of Business Economics, Business Statistics, 1967 for data to 1966:4, and various issues of the Survey of Current Business for subsequent data

FRSL Federal Reserve Bank of St. Louis, unpublished data

RJG Robert J. Gordon, "Problems in Predicting the Rate of Inflation," paper presented to the Econometric Society meetings, New York, December 30, 1969, pp. 36-50

SCB 1966 Supplement to the Survey of Current Business for data to 1963:4, and various issues of the Survey of Current Business for subsequent data 


\section{Comments and Discussion}

Robert Solow: My comment number zero is that the paper demonstrates that the accelerationist idea of inflation gets essentially no support from the data—confirming my own work and that of others. I would suggest that we leave that theoretical question out of our discussion unless somebody has something new to offer.

Comment number one is on the 1969 results. In 1969, most measures of excess capacity were steady or rising. The unemployment rate was steady. But the rate of inflation actually accelerated over 1968. If there is any surprise in the behavior of prices in 1969, it is that the rate of inflation wasn't lower than, in fact, it was. Yet Gordon's model predicts a higher rate of inflation than actually occurred throughout 1969 and especially in the first half. Why does this happen? The main independent variable of the wage equation is the rate of change of the specially constructed unemployment rate. This calculated unemployment rate of manhours fell fairly sharply through 1969 , especially the first half, while the conventional unemployment rate was level. There is also excessively rapid growth of the labor force-a jump in the participation rate in 1969.

If you believe that the official unemployment rate gives a more accurate picture of what was happening to the labor market in 1969 than the constructed manhour unemployment rate, then you have an explanation of why the equation predicts an even faster rate of inflation than actually occurred.

I would have thought that the slow growth of productivity in 1969 (as expressed by the large increases in current unit labor cost) could not be a major part of the explanation of the overprediction of inflation, because 
standard unit labor cost, which would be unaffected by that, has a weight in the wage equation four times as great as current unit labor cost.

The explanation of productivity growth in the paper is troublesome. It is expressed as the rate of growth of output minus an estimate for the rate of change of aggregate manhours. In the resulting estimate, productivity grows faster when unemployment is increasing. This says if the unemployment rate were 3.5 percent, an increase in the unemployment rate would speed up productivity, and I am not sure I would buy that. The usual picture is that periods of increasing unemployment are not, other things being equal, periods of extraordinary productivity advances.

My second comment is that I was interested to calculate the steady-state trade-off between the rate of change of the price level and the conventional unemployment rate in the Gordon model. I conclude that 1 point on the conventional unemployment rate reduced the rate of rise of the nonfarm deflator by a little more than 1 percentage point per year.

Finally, I want to point out another doctrine that doesn't stand up, if this model is an acceptable one. That is the assumption that there is a long lag between economic activity and the rate of inflation. There is no long lag in this model. The distributed lag effects of wage increases on prices sum to 0.95 , so that prices are roughly proportional to wages. Of that $0.95,0.53$ occurs in the current quarter. Another 0.24 operates with a one-quarter lag and 0.13 operates with a two-quarter lag, so at the end of two quarters you have 0.90 of the 0.95 effect. This notion of storing up trouble for very long periods of time is not borne out by these figures.

There is some further lag built in through the expected change of the consumer price index in the wage equation. That is dampened a little because it exerts only half its weight on unit labor costs. But, even so, the first three quarters account for at least 60 percent of all the weight on lagged changes in consumer prices.

This, of course, shows up in the projections for 1971-75. As soon as the real economy starts rising, or very soon thereafter, the effect on the price level shows up. So the long-lag story is not supported by this paper.

George Perry: In reviewing Gordon's paper, I agree with Robert Solow that what is most relevant is not the theoretical debate about acceleration, but what the model tells us about where we are and where we are going.

My chief concern is with the manhour unemployment rate, which is the main ingredient in the particular regression results and in the explanation 
of 1969. Actual manhours, from the fourth quarter of 1968 to the fourth quarter of 1969 , went up 2.3 percent in the private nonfarm sector. Potential employment probably rose between $1 \frac{1 / 2}{2}$ and 2 percent in that interval. If a normal decline of 0.2 or 0.3 percent in average manhours is allowed, a decline of even 1 percent in the manhours unemployment rate is hard to achieve. Yet Gordon's rate declines by 2 percent and is a very big part of the story. I am skeptical of this decline shown in the calculated rate and would like to know what assumptions led to it.

I also have a couple of more fundamental questions about the adjustments that are made in going to the manhour unemployment rate concept.

First, I have never been persuaded that you ought to count as unemployed those people who are not actively seeking work, but who we're told by some participation rate equation would enter the labor force if the employment rate reached a certain level. What participation rate equations say is that if you expand employment by a certain amount more people will start looking for work. This says something about how fast labor markets will tighten as you expand output. It is not the same as saying that these marginal workers should be given equal weight with someone actually unemployed when you are trying to measure how tight or loose the labor market is at a particular time or output level.

Second, I am not convinced that bodies and average hours deserve equal weight in an unemployment measure. Gordon's equations describe as equally tight a labor market with a $31 / 2$ percent unemployment rate and a 40.0 hour workweek, and one with a 5 percent unemployment rate and a 40.6 hour workweek. My intuition strongly tells me that a $3 \frac{1}{2}$ percent unemployment rate and a 40-hour week mean a much tighter labor market. If so, hours and bodies should not be combined into an overall index.

Finally, in regard to Solow's point about lags apparently being short, one place where the lags seem to be present is in productivity. What happened in 1956 and what happened in 1969 is hard to explain, but we shouldn't pretend that it isn't part of the world. You do slow down output for a long time before you unwind something like the present inflation, even though it doesn't show up in an equation that takes unemployment and productivity as given.

R. J. Gordon: Let me first explain how manhours enter in and why they contribute to the sharp drop in the manhour unemployment rate in 1969. The trend of potential manhours is estimated by connecting actual 
manhours at peaks of economic activity. For the last few years, I connected a peak in early 1965 with the peak quarter of 1969 . In this interval, the trend line drops much faster than it did over the previous decade. I cannot say how much of the shortfall from the previous trend line is cyclical, due to part-time workers, and how much is secular, due perhaps to a decline in hours in the service industries.

The important point is that, although actual hours per worker did not rise in 1969, they did not continue to fall in step with the new trend line. Thus measured against the sharp drop in the trend line, manhours rose, helping the manhours unemployment rate to drop sharply. If the trend line were changed, the inflation of 1969 would not be overpredicted as it now is in my analysis.

On the question of productivity, the model identifies two kinds of effects. First, by including a distributed lag on past changes in output in the manhours equations, it captures the expected cyclical behavior of productivity. But there is an additional diminishing returns effect, implying that during periods of steady growth in output, the level of productivity will be positively related to the unemployment rate.

\section{General Discussion}

Several participants questioned the author about the decisiveness of his evidence against the accelerationist thesis. Paul Samuelson asked how his findings squared with the accelerationist empirical results set forth by Leonall Andersen and Keith Carlson of the Federal Reserve Bank of St. Louis. Gordon and Robert Solow agreed that Andersen and Carlson did not genuinely test the accelerationist hypothesis, but instead essentially built that theory into their model.

Gordon insisted that he had given the accelerationist hypothesis a genuine chance in his research: He had tested a variety of possible time patterns for expected prices, and all patterns showed that the impact of prices on wages was substantially less than proportional, contrary to the accelerationist view. He had even assumed proportionality, forcing the expected price variable to take on a coefficient of 1 in the wage equation; but then he obtained very poor explanations and predictions of actual movements.

Robert Hall, however, argued that the findings had to be qualified: "The accelerationist theory has never really been tested in the postwar American 
experience. We have not had a sufficiently sustained inflationary experience to generate acceleration. Yet the Gordon paper essentially runs through a high employment projection that would produce a sustained inflationary experience of chronic $33 / 4$ percent inflation accompanying 3.8 percent unemployment. Gordon has shown that there is a perfectly consistent view of what has happened in the last twenty years that does not rest on the one-for-one transmission of prices into wage increases. That doesn't really say that the accelerationist thesis is definitely wrong."

Hall offered as an example the possibility that people form their expectations of inflation by extrapolating the actual minimum rate of inflation in the previous five years. Under those circumstances, one would not be able to confirm the accelerationist thesis at any time in the postwar period even if it were entirely correct.

William Fellner made a related point about interpreting evidence. A tightening of stabilization policy has sometimes, as in 1952-53 and 1960, had a noticeable effect in slowing prices before it substantially raised unemployment, as these magnitudes are measured by Gordon. Such episodes would generate misleading evidence against the accelerationist thesis.

In response, Gordon pointed out that since we have now had four consecutive years of high employment and inflation, any process of accelerating expectations should be reflected in his model results, and none is visible.

Solow speculated: "If we were actually to live in an economy in which the price level rose by 4 percent a year-year in and year out-the accelerationist hypothesis would probably show up more strongly in the data than it does now." But Solow found it hard to believe that the performance of an economy with a steady 4 percent rate of inflation would be substantially different from the performance of one with a random mixture of 2 percent rates half the time and 6 percent rates the other half.

David Fand probed the influence of social security taxes on inflation in Gordon's findings. If this result is accepted, he suggested that a reconsideration of payroll taxes would be desirable for public policy.

Only a few participants expressed reservations about Gordon's findings that high employment and price stability are incompatible goals. William Branson noted that Gordon's own statistical findings pointed to a considerable range of uncertainty. The best-estimate numbers are not reliable enough statistically to rule out the possibility that high employment and price stability may be compatible. 
Lawrence Klein followed up Branson's optimistic note, stressing the partial nature of the Gordon analysis. He argued: "The composition of resource use and the composition of output are very important to price stability and they are really not considered in the Gordon model. For example, Gordon's two equations say nothing about the influence of the war on inflation. If you analyze the effect of war on productivity and on the mix between private and public investment, you can see there are a number of things left out. It may well be possible to devise a scheme with a much lower rate of unemployment compatible with a peacetime economy and not have the same degree of inflationary pressure." 